\title{
Overlapping and Conflicting Interests as Opposed to Integration and Disintegration in Iran-India Ties 1947-1979
}

\author{
Mohammad Mehdi Mirzaei \\ Islamic Azad University Karaj Branch, Karaj, Iran \\ Mohammad Taghi Amrollahi \\ School for International Relations of Ministry of Foreign Affairs, Tehran, Iran \\ Suroush Amiri \\ Ameen University, Tehran, Iran
}

\begin{abstract}
In the period between independence of India in 1947 to Iranian Islamic revolution in 1979 there were plenty of factors in the position of integration and disintegration acting in the relationship between the two countries. Iran and India, whose result is meaningfully affected by factors in three levels of national, regional and international sphere and in the framework of bipolarity as the predominant system in the then international system. The ties in the critical period of cold war between two superpowers that came after the World War II were full of ups and downs. Undoubtedly the true perception of such an atmosphere needs to pay attention to the factors of integration and disintegration, which are interdependent and directly or indirectly impact each other and the finalized atmosphere of mutual relations. Knowing the atmosphere is not only important historically but also it enables researchers to evaluate the different factors within the relations and to interpret each of them critically, meaning that the root of disputes, influence of global events and external factors in mutual relations, changes the politician point of views and the political mainstream patterns, and finally to mention the strategic and geopolitical situation regarding the influential factors of integration or disintegration. At the end, the cleared results open a new foundation in order to make new researches which can help to make formula to futurism and be useful in practical sphere.
\end{abstract}

Keywords: Iran, India, mutual relations, integration, disintegration, foreign policy

\section{Introduction}

Iran and India - two countries have years of living in their neighbourliness - are strongly affected by each other and have deeply rooted relations for years. They exchanged number of ambassadors for specific events before the British hegemony in Indian subcontinent, but there was no direct official relation in the last king of Mughals in 19th century, almost approximately 1857 to 1947, when it became officially part of British Empire (Political Division, 1976, p. 182). The mentioned relations, which represent itself, more obviously in cultural, literary and trade spheres, have been changed by the Indian independence milestone and started formally in 1950 in a mutual political framework.

In spite of the fact that the inauguration of relations was positive and hopeful, besides the indisputable requirements in fields such as economy of two countries, which played a regulating role as an internalizing, 
factor in their relations, the political struggles under the cold war to the relative orientation and variety of their friends in comparison to each other along with a great deal of interfering factors which changed the atmosphere of relations, make it far for the two counties to fulfil the idealistic shape of it and finally it was shaped by the external conditions (Pant, 2008, p. 114).

For instance in the 60th century while the relations between USA and USSR were ongoing in phase of détente, Iran found new capacities to think about making meaningful relations with USSR (Gasiorowski \& Byrne, 2004, p. 2) and took it as an advantage to enhance the possibility of catering its needs and wills regarding with its old friend, India.

Concentrating to the referred factors which had more weight in shaping of the mutual relations of two powers in Asia, namely Iran and India, it would be mentioned and explained over the major integration and disintegration factors in the framework of international relations.

\section{Integration Factors-Common Social and Historical Inheritance}

Jawaharlal Nehru (1983) says about the depth of cultural relations between the two countries: "out of nations and tribes few people have been more closely related in origin and throughout history than the people of India and the people of Iran".

Iran and India desire to speak of their civilization building ties more than any other subject (Desai \& Dormandy, 2008, p. 1). Their ties which go far back in history to the entrance of some of Aryans to India put the two countries under the influence of common myths and history (Jalali Naeini, 1996, p. 6) even though there is something beyond it called being part of East with all the aspects it resembles.

All over the time it would be rarely the active long-rooted such as what exists between the two countries of Iran and India for thousands of years which can be found in the replicas of Muhenjudaru and the civilization of Sind. However, Aryans went to Europe after their first separation and divided in two groups: some chose Persian Plateau and Central Asia and others departed for the subcontinent and stayed in the northern India neighbouring to Dravidians.

From the very first, the relations were according to friendship and good neighbourhood despite all the disputes and invasions of Iranian kings such as Nader Shah and Mahmoud Ghaznavi to India is yet according to the common cultural-civilizational values. If we consider presence of Persian as a language, it reached India in the era of Ghznavids and by the establishment of the emperorship of Mughals in seven centuries as an official and judicial in India and it shows the cultural influence of Iranian in India and on Indians.

If we look at the Islamic period in India, we find the prominent importance of Iranians in the expansion of Islam via Persian in India where fellowship of both tribes strengthened and even the Dravidic and Brahmaiisim (Hinduism). In the post-independence period intellectual open-minded figures such as Gandhi and Nehru have an undeniable effect on the Iranians to refer to their Iranian-Islamic traditional values.

Student-teacher exchange agreed in 1973 between Iran and India, regarding to the agreements signed Sanskrit in Iran and the seat of teaching Persian in India (IPIS, 2010, p. 218).

During the three decades of Iran-India relations besides all the political orientations, the dead end in the political competition of east and west, and the path of preservation and expansion of the relations of Iran and the social civilizational body of India lived on faster. The outcome were the two Iranian Shah long-term visiting, one in 1965 for 22 days and another in 1978 which came about the closeness in the countries on the contrary to the viewpoint of analysts and justified to some that extend the political dissidence. 


\section{Traditional Trade and Commercial Ties}

The background of Iranian economic and commercial ties with India came back to pre-Islamic era. At that time, trader's commerce via their ports trade on industries, spices, drugs, and textiles. This one came fruitful in the way of Sind and Punjab and reached to its highest point.

During the Safavid dynasty, India was one of the greatest partners of Iran in trade and there were exchange of a big volume of domestic and non-domestic goods. A number of traders of both sides came to each other's portal sites, cities and economic centres and made the powerful cycle of transferring goods. The reflection of ports, ways, and the role of tribes and classes involvement in trade cycle represent the intermixture of relations (Soltanian, 2009).

Under the British rule, most of the Iranian in India were the traders, merchant and businessmen who were under pressure to do their job in their own country so that they had come to India and at the same time they keep Iranian relations with Indian side alive and powerful (Political Division, 1976, p. 182).

The very first agreement on trade was signed in 1954, later in 1969 first joint commission of two countries took place in a meeting in which the ministers of economy and economic area requirements of two countries met and agreed on. They also signed the agreement of MFN (most favoured nations) to facilitate the relations, inter alia, the commercial relations (Political Division, 1976, p. 187).

Economic ties were not as much powerful as the very starting of independence to glut the dissidence in political stance of two states (Naz, 2001, p. 565), but slowly those relations were highlighted even it came before the cultural ties as the centre of gravity (Scott, 2011, p. 172). India allowed the Iranian part to invest in Kudormokh ironstone in 1974 and instead benefited of Iran's oil (M. Porgu \& Jamshidi, 2007, p. 3). Formation of joint shipping company by the capacity of 500,000 tons was another step in the relations between the two countries (Dastmalchi, 2014, p. 208).

Even though another war in accordance of placing two countries further to each other occurred, but the capacity of the trade between them was as perceptible at this time as the exchange rate at the moment clears Pakistan's inability to compete with the Indian counterparts, so that it resulted in changing or better to say forced Iranians to tilt toward Indians because of the far reaching economic exchanges rather than the traditional perspective and to consider India as a trade partner which can benefit and confident to Iran.

\section{Economic Common Market}

After the Zafar rebel and Iranian role in calming down the rebellions of Oman, while Iran was slowly far from USA, they stated negotiations with Indian Prime Minister Indira Gandhi. The result of talks was the opening of a common market of triple Iran, India and China, it would immediately guaranteed the regional security and then paved the way for Iran to secure its position as a regional power along with two traditional powers of the region. At the same time, it limited the roles of USA and USSR, who were on the way to choose the field of competition among smaller actors.

In other words it highlights the Iranian role as a mediator in Indo-china relations as a friend of both sides to secure the security of the region from the Persian Gulf to the Indian Ocean in a standstill cycle (Dastmalchi, 2014, pp. 173-175).

The project faces to many challenges despite all Iranian attempts to build an Asia model of European common market, Arabian states were anxious about the increasing role of Iranian dominance in the region and Pakistan was afraid that such a market would be turned into Indian geopolitics privilege in Indian Ocean area. 
In 1977, Pakistan and Iran, along with Turkey, previous members of the Central Treaty Organization (CENTO), signed a new Treaty called Izmir at first then renamed to Regional Cooperation for Development (RCD). Its structure failed to reach its goals, by the Islamic revolution of 1979. It reappeared once again in 1985 as the Economic Cooperation Organization (ECO) which represents the necessity of a comprehensive economic community in the region.

\section{Iran-India Needs}

Even though an Iranian delegation extended their friendship to the nation and state of Indian in 1947 within the Asian Relations Conference, the mutual relations was started by the recognition of India and promotion of head consulate of Iran-India to an embassy which resulted in diplomatic ties directly and officially through the official paths. The relation started in March 15, 1950 by the permanent peace and friendship agreement (Towhidi, 2008, p. 156). The defined needs of two countries under the national interests were developed by the awareness of elites and decision makers of two sides about the capacity of the other side. The needs made it possible to develop the ties even in the sour years of relations, in a way that two parities consider each other a confident and rich to complement the mutual requirements.

Shah visited India in 1956 in response of his visit from Prasad which was truly answered by Indian president. Cultural Agreements of 1958, 1964 and Economic Contracts of 1960 made it possible to develop the political relations which itself came to recession by the 1965 war of India and Pakistan (Dastmalchi, 2014, p. 202).

Indian need of buying Iranian oil and vice versa for Iran to sell it as natural energy resource especially by the 1960th was an important issue which revolved the relations in the sphere of oil selling, buying in the economic framework to be a strategic subject. Iranian partnership in Madras refinery, an iron mine in Kudearmukh by the capacity of 50,000 barrels started in 1969 in south of India. However a devastating atmosphere arose in India by the oil shock of 1973 which made the oil price multi times of its natural price. Indian, who encountered to a difficult situation, decided to prepare a visit by Indian Prime Minister Indira Gandhi to receive enough supply for energy requirements. Consequently to Gandhi's visit and venae in 1978, Iranian Shah 13-days visit took place which was the last one of its visit likewise before the Islamic revolution in Iran (Niakoui \& Bahrami Moghaddam, 2014, p. 126; Dastmalchi, 2014, p. 203).

\section{Iranian Support of India During India-China War}

India-China War of 1962 and support of India by Iran during this battle on one side and rising of boundary disputes between Iran and Pakistan, which was along with Pakistani closeness to China, came in Iranian closeness to India as a factor to balance region against Pakistan-China transactions.

Disputes increase over the tension of Dalai Lama's Tibetan spiritual leader, dissidence with the Chinese government. India by giving political asylum to opponents of Chinese government put fuel on fire and finally the disputes on Himalayan boundary made a pretext for a war.

Meanwhile Iran alongside with Americans and British whom were afraid of communism, hastened to help India by Heli board of military weapons though they were be aware of India's ties with Russia and it was important in future Pakistani actions verse China which transhipped to a friendship lately (Dastmalchi, 2014, p. 103). In this event the objective for help by Iran was to reduce Indian dependence to USSR and motivate it to keep Persian Gulf side of Indian Ocean from the presence of Russians (Tishehyar, 2011, p. 131). 


\section{Indian Ties with Israel}

By the victory of the independent movement of Indians against colonization, mainstream viewpoints of Indian people and officials support of liberalization movements and fighting with the tyrannies and violent. One of the same like picture is the quarrels between people of Palestine and Zionist regime. India, according to the moral policy which followed in the first decade after independence and despite the pressure of internal Islamic groups encouraging support of Palestinians and Quds, recognized Israel in 1950 and grew as fast as Israel - called India the second hometown which shows eye-catching signals beyond the curtain of their relations (secret visit of Israeli's to India during Congress rules) (Niakoui \& Bahrami Moghaddam, 2014, p. 148). Indian Muslim societies and Arabian countries' pressure on Indian official was on the way not to let Israel to join nonaligned movement which kept going as the Nehru's thought of morality to limit the expansion of relations (Simbar, 2015, p. 98).

Iran also recognized Israel, which made its relation darker than before with its Arabian neighbours, and chose Israel as a friend according to American wills as true friend. Regarding the two phases in Indian foreign policy, the first one didn't seem to be worse reason for minimizing the Iran-India relations but by passing the time until the Islamic revolution formation of India and Israel ties partly secretly but stable result in consensus about the south western Asia made the two countries in the same boat against Arabian states which was considerable for Iran, however India was anxious about losing its Arabian allies who were the suppliers for energy and at the same was wise enough to build an Arabic integration to weaken Pakistani power so that it carries on relations with Israel in a concealed diplomacy.

\section{Disintegration Factors}

\section{Iran Alignment with the West Bloc and Indian Closeness to the East}

Nehru in one of his speech in Lahore before the revolution pointed out Iran and Iraq as two countries who are not independent and counted them as part of east and west satellites, consequently Iranian diplomat in New Delhi Motamdi wrote in his letter for Nehru with all respect that you denounce my country and my nation, I would like you make it clear because I am aware of your knowledge and in response Nehru said I know Iranian culture and I respect it but a large number of countries even Britain is somehow a Satellite for USA so what is important for us is to be a county all independent (Political Division, 1976, pp. 184-186).

From the very beginning of independence, India became one of the founders and pillars of the third front in global society namely non-alignment movement and Nehru besides Sukarno, Tito, Abdonnasir and Nekrume joined as one of the leaders in this movement. India still wanted to be one of Iranian friend since they follow non-alignment and they have cultural and economic ties and interests. But by the time coup d'état occurred against Mosaddiq national government which confirmed the increasingly interference of western belt meaning USA and UK in Iranian policy making the relations of Indo-Iranian soured.

Shah in Iran wanted to follow the Truman Doctrine perfectly so that by the presence of USA in Iranian political scene and development of mutual relations of Iran and USA, the role of UK and USSR decreased, which was a reaction to the disasters and casualties which took place by those countries in Iran in the past. For example, even though Iran declared that it would follow neutralism in World War II, aligned countries came to Iran, occupied it, ransacked resources, food, bread etc. of Iranian for their own soldiers and imposed to Iranian their own social system. USSR alone was a great supporter of Tudeh party which was absolutely against Shah's 
attitudes toward the world (Simbar, 2015, p. 86) and it threatens Iran's integrity so that their support exacerbates the situation (Fair, 2004, p. 8).

Iran joined to the western allies officially by Shah's command to join CENTO (Baghdad) pact in 1955. The pact, which was one of the treaties, booster to American iron curtain and containment doctrine against USSR had its own opponents who defend of negative equilibrium strategy and one prominent person was Iranian national figure Mohammad Mosaddigh. Among the countries, India which was on the opposite side to the military pacts in the region, considering those tantamount to violation of international peace, pointed out that pact as an unfriendly action and regarded it on accordance to Pakistani interests.

American cooperation with Iran in defence arena was not limited in CENTO, mass military helps and mutual security cooperation alongside the joint manoeuvres strengthened Iran as one of the serious allies of USA in the region. The volume of military exchanges reached to 600 million dollars in Johnson time, which sold to Iran in five years aimed in securing the security of Persian Gulf (Dastmalchi, 2014, p. 65).

But India was in another context. India was trying to limit American intervention for 40 years mostly because of American expansionism, not necessarily the anility in relations. In spite of the fact India was nonaligned to both sides superficially and stepped forward to defend of liberation movements and third world countries, but it was in strong linkage with USSR which made it possible for India to provide military logistics and weapons by the USSR and at the same time acted as a balancing actor in relation with the weights of American position in the world.

India's relations with USSR grew as fast as it became the biggest provider of Indian military needs soon (Simbar, 2015, p. 86) and the increasingly procedure of ties rose to its highest point by contract on cooperation and friendship in indri Gandhi's period.

India helps Bangladeshi refugees in Bangladeshi Independence War, however it was justifiable by political orientation, India faced a new atmosphere involving that war. India captured 90,000 Pakistani soldiers and ended the war in accordance to Bangladeshi independence explorers and of course soviet unions (Dastmalchi, 2014, p. 72). The arrival of Bangladesh and Iranian worry about India-Bangladesh closeness was a sign for future developments in favour of USSR. Iran came near to USSR in a specific time but it was wary and limited and Iran resisted against soviets' expansionism policies.

Moreover, Indian closeness to the Arab revolutionary countries of the time, especially Egypt, was never justifiable for Iran. Leaders like Jamal Abdunnasir who claimed a viewpoint of pan-Arabism to array a front of Arabian states against the western axis was unpleasant to Shah (Naz, 2001, p. 563). Arabic nationalism was attractive to Arabs who were being humiliated by USA and Israel and support that idea. Arabs did not only support the reaction but also nationalists all over the world including India who were against the unilateralists supported. Egypt was one of the two bases for Sunnis and the location for Alazhar, prominent Sunni university, which extended the tribal confrontation to Iranian. Therefore, Shah took the advantage of using Islam as an anti-ideology against Nasserist and arranged the Islamic conference organization in the 1960s as a tool to gain prestige apart from Arab league, which was in Arabs kingdoms' hands (Naz, 2001, p. 563).

Indian closeness to Iraq and Egypt and their silence about the entrance of soviets forces to Afghanistan breached their place in world public opinion, Non-Aligned Movement (NAM) slammed it, and USA challenged Indian relative authorities by the development and fulfilment of Diego Garcia base. 
Concerning the US critical stance of caters period which put Iran under pressure of human rights and freedom of speech, Iran decided to cooperate with India. India looks at Iran beyond the reality of global poles at the same time. Iran was a confident and responsible country on the contrary to Arab partners specifically the Persian Gulf states.

Shahs' second travel to India which dealt with disarmament, Middle East issue, and kept the safe of Indian Ocean region happened in 1978 as a way to strengthen the relations (Naz, 2001, p. 566), which was in the last months before the overthrowing of Pahlavi regime.

\section{Iranian Support of Pakistan}

Iran attempted to show an active role by the indolence of India and Pakistani separation plan to safeguard the western interests according to American anti-intervention policy. There was another reason as well as the international system divisions - being Muslim of majority of Pakistani people and its Islamic system which was in a close tie with Iranian and pushed them to create an Islamic sub bloc (Pant, 2008, p. 114).

There is the common boundary as another reason. While once British India was an immediate neighbour for Iran, the new component of Pakistan reshuffled the regional equivalents.

The official separation of Pakistan from India resulted in tensions between India and Pakistan and had no outcome but killing of hundred thousands of people: Muslims, Hindus and Sikhs, which also made survivors homeless. Iran as the first country recognized Pakistan in 1947, along with the Shah of Iran's travel to Islamabad in 1949, two contracts of friendship signed (Niakoui \& Bahrami Moghaddam, 2014, p. 125). India, which lost a great deal of its soil in this condition and has started its relation with Pakistan by conflicts, dissatisfied with Iranian behaviour and the process continued by Iranian support of Pakistan, or better to say, US military and security wills in the Indo-Pakistan wars which were justified by CENTO. CENTO was a defence treaty in which Iran, Pakistan and turkey joined as well as the US and the UK (Fair, 2004, p. 8).

This factor helped Egypt as political pressure on Iran. Once Indian newspapers reported by quotation from Egyptian sources about Iranian logistic helps to Pakistan, which made Indian anger at Iran who protested in front of Iranian consul in Mumbai and Iranian embassy in New Delhi (Mehri Porgu \& Jamshidi, 2007, p. 4).

Iran-India relation was not all alike between the tensions. For instance, in the strife of 1965 war Shah took a message secretly for Ayyoubkhan and asked him to end the hostilities (Dehghan \& Kazemi, 2011, p. 64). In this time Iran limited its support to statements and some specific types of logistics. From this point of time Shah took a decision to observe the relations in two separated areas. In the late 1960s Iran's perspective toward Pakistan has changed dramatically — affected by Pakistani closeness to eastern bloc and especially Pakistani different votes in comparison to Iran's favours in international organizations which balance the relations. However, thanks to the special mechanisms Pakistan benefitted, they achieved Iranian approval of transferring a large number of fighters against India in 1971 (Tishehyar, 2011, p. 130) as well as obstructing India's presence in Islamic conference in Rabat in 1969 (Sikri, 2009, pp. 27-30).

The 1971 war of India-Pakistan changed the equilibrium once again, even though after the last war all disputes have not been settled but the Seemla agreement between Indian prime minister Indre Gandhi and Pakistani President Zulfikar alibhuto made it simple and possible for Iran to exercise its own foreign policy departing from Pakistani factor (Dehghan \& Kazemi, 2011, p. 68). 
By the continuity of Iranian relative support of Pakistan in 1973 Indian newspapers questioned if another war took place, weapons bought from Iran will be used or not. This view was tensed by Iranian strong stance: Shah of Iran in an interview with an Indian newspapers said that if Pakistan was invaded, Iran will stand beside it and this made a harsh atmosphere against Iran in India (Dastmalchi, 2014, p. 203).

Iran-Pakistan joint plan to suppress Baluch rebellions in their shared boundary with Afghanistan in 1970s and the Iranian financially assistance in Pakistani infrastructures even as it is believed in their nuclear facilities made their friendship a real brotherhood rather than a relatively coalition (Tishehyar, 2011, p. 130).

After years Shah understood that USA as the major ally of Pakistan had not acted as an active actor in Indo-Pakistani conflict so that he slowly abandoned that harsh stance. Pakistan voted against Iranian opinion in Bahrain's join to the United Nations Educational, Scientific and Cultural Organization (UNESCO), meanwhile Pakistani tried to follow détente policy toward Arab states especially Egypt, altogether this set of event mad Iran to be assured of its revisions.

\section{Iranian Attention About Muslims}

Iranian attention about Muslims is explained through India, Pakistan, and Kashmir in there subfields. Indian Muslim seem to be more important than other groups in this categorization because they have committed to the cultural ties and favours with Iran during hundreds of years especially within Mughal emperorship and know Persian as the language of their religion which make it crystal clear that where the depth of relations has vested. Moreover, the population of Indian Muslim who form 200 million of Indian population have made sensible and anxious the authority about political Islam and the radical and fundamental interpretation of Islam (Simbar, 2015, p. 28). Although Muslims have involved in the government and official mechanism in India, a comprehensive perspective about them did not exist in terms of development and Muslim populated areas are facing with poverty and social problems considerably.

On the other side Muslims have been worried by the propaganda of radical groups such as Rashtriya Swayamsevak Sangh (RSS) and Vishva Hindu Parishad (VHP) and plenty of them immigrated to Islamic countries to live safe and respected. Considering that 35 percent of indium Muslims are Shia and the Muslims population included 13 percent of the whole country, the significance of this numbers of Shia population will be obvious for sources of emulations and Shia cleric proselytizers.

Britain declared the annexation of Indian and Pakistani states according to three ways: the first one was the closeness of the state to India or Pakistan the second one was the religion of majority of the states, and the third one wills of each state. The determination of Kashmir does never have obvious since there exist an internal struggles between raja and people in attaching to India or Pakistan and some asked for the independence so that the armed people of local tribes attacked Sringer and it resulted in the first war between India and Pakistan. The crisis in the relations of India and Pakistan still goes on as the human plight of the region.

\section{Conclusions}

Ups and downs in Iran-India relations in the time after independence of India and before the Islamic revolution of Iran is not a understatement but what can be forgotten is the ignorance of the long standing of the relations in the political context, which even keeps on after the discussed period of time according to the preconceptions in all aspects. This doesn't mean of course to deny the deep changes in Iranian political 
atmosphere after the revolution but what should be regarded is the presence of factors in the strategic and tactical spheres whether as facilitator or obstructions.

The importance of Indian Muslims as a significant minority is one of those factors, which put shadow on the ties since Iran followed the revolution idealistic and self-extension policies. The relation with Israel was another factor that existed to some extend in both countries; India avoided it to be revealed; but both countries developed their security, military and defence spheres requirements in the relation and transaction with Israel in general. After 1979 revolution Iranian perspective toward Israel have been changed dramatically and Iranian insistence on the worry came about-India is the real strategic relations which would be considered as a hurdle to deepen the Iran-India relations respectively.

The issue of relations with Pakistanis and Arabs was real and resulted in the periodical weakness and short term integration in terms of part of the agendas dealing with those categories.

What is noteworthy is that, even though most of the aspects of relations were formed in the context of bipolar international society, searching for freedom and idealism of both the nations which in Iran did not arrived at government, turned on the machine of cultural inheritance and likelihood.

Today, taking the advantage of common experience of two countries in lack of time for trial and error and in the transition era of the moment is absolutely vital. Iran is a country enjoying the natural resources, scholar elites and potential workforce and defending multilateralism in international relations will be important for India as a rising power and in need of energy for its economic growth continuity. In other point of view, India has reached to an outstanding growth in high-tech and IT and the eagerness to invest in Iranian market in energy, transit and transportation areas will be possibly regarded as an indisputable economic participant for Iranian.

\section{References}

Dastmalchi, A. (2014). History of Iran and India relations. Tehran, Centre for International Education and Researches, Foreign Ministry Office for publishing.

Dehghan, Y., \& Kazemi, M. (2011). A survey on Iran-India relations under the shadow of emerging India as a regional power (in Persian). Tehran, Abrar Moaser Tehran cultural institute for study and research.

Desai, R. D., \& Dormandy, X. (2008). India-Iran Relations: Key security implications, policy brief. Belfer Center for Science and International Affairs, Harvard University, March 24.

Fair, C. C. (2004). Indo-Iranian relations: Prospects for bilateral cooperation post-9/11. Asia program especial report, No.120.

Gasiorowski, M. J., \& Byrne, M. (2004). Katouzian writing in Mohammad Mosaddeq and the 1953 Coup in Iran. Publisher: Syracuse University Press.

IPIS. (2010). India (green book). Tehran, Foreign Ministry Office for publishing.

Jalali Naeini, M. R. (1996). India in a glance. Tehran, Shirazeh.

Mehri Porgu, V., \& Jamshidi, M. (2007). Indian foreign policy behaviour toward Iran (in Persian). Tehran, centre for Majlis researches.

Naz, F. (2001). Iran-India relations 1947-2000 (in Persian). (I. Shafiei, Trans.). Foreign Policy Journal, 15(2), 555-571 .

Nehru, J. (1983). Discovery of India (in Persian). (M. Tafazzoli, Trans.). Tehran, Amirkabir.

Niakoui, S. A., \& Bahrami Moghaddam, S. (2014). Iran-India relations: Opportunities and limitations (in Persian). Ravabet-eKhareji Journal. 6(1), 123-160.

Pant, H. V. (2008). Contemporary debates in Indian foreign and security policy. New York, Palgrave Macmillan.

Political Division. (1976). Developments of kingdom state of Iran relations with Afghanistan, Bangladesh, Pakistan, Turkey, Sri Lanka, Nepal and India during the fifty years of kingdom. Tehran, office for publication and documents.

Scott, D. (2011). Handbook of India's international relations. London: Routledge. 
Sikri, R. (2009). Challenge and strategy: Rethinking India's foreign policy. New Delhi: Sage.

Simbar, R. et all. (2015). Indian foreign policy. Rasht, University of Gilan.

Soltanian, A. (2009). Iran-India commercial relations in Safavid dynasty era (in Persian). Tarikh Ravabete Khareji, 40, 55-78.

Tishehyar, M. (2011). The dynamism of Iran-India relations: 1979-2009. Iranian Review of Foreign Affairs, 2(2), $127-156$.

Towhidi, U. A. (2008). Capacity and limitation in Iran-India relations, no. 47 (in Persian). Centre for Strategic Researches of Excellency Council. 